\title{
Sulphate and Chloride-Dependent Potassium Transport in Human Erythrocytes are Affected by Crude Venom from Nematocysts of the Jellyfish Pelagia noctiluca
}

\author{
Rossana Morabito ${ }^{a}$ Angela Marino ${ }^{b}$ Pietro Romano ${ }^{c}$ Caterina Rigano ${ }^{d}$ \\ Giuseppa La Spadab
}

aDept. of Human and Social Sciences, University of Messina, ${ }^{b}$ Dept. of Biological and Environmental Sciences, University of Messina, 'Laboratory, Hospital "Maggiore", Modica, ASP 7 Ragusa,

"Orthopedics, Hospital "S.Vincenzo", Taormina (ME), ASP 5 Messina, Italy

\section{Key Words}

Erythrocytes • Oxidative stress • Band 3 protein $\bullet \mathrm{GSH} \cdot$ Crude venom • Pelagia noctiluca

\begin{abstract}
Background: It has been reported that biologically active compounds extracted from Cnidaria venom may induce damage by oxidative stress. Erythrocytes are constantly exposed to oxidative stresses, which can contribute to sulphydril (SH-) group oxidation and cell membrane deformability accompanied with activation of $\mathrm{K}-\mathrm{Cl}$ co-transport and inhibition of anion transport. In this regard, Band 3 protein is responsible for mediating the electroneutral exchange of chloride $\left(\mathrm{Cl}^{-}\right)$for bicarbonate $\left(\mathrm{HCO}_{3}^{-}\right)$, particularly in erythrocytes, where it is the most abundant membrane protein. The aim of this study was to elucidate the effect of crude venom extracted from Pelagia noctiluca nematocysts on Band 3 -mediated anion transport in human erythrocytes. Methods: Erythrocytes were tested for $\mathrm{SO}_{4}{ }^{2-}$ uptake, $\mathrm{K}^{+}$efflux, glutathione (GSH) levels and concentration of SH- groups. Results: The rate constant of $\mathrm{SO}_{4}{ }^{2-}$ uptake decreased progressively to $58 \%$ of control with increasing venom doses, and showed a $28 \%$ decrease after $2 \mathrm{mM}$ NEM treatment. These effects can be explained by oxidative stress, which was reflected by decreased GSH levels in venom-treated erythrocytes. Hence, the decreased efficiency of anion transport may be due to changes in Band 3 structure caused by SH-group oxidation and reduced GSH concentration. In addition, an increased $\mathrm{Cl}^{-}$-dependent $\mathrm{K}^{+}$efflux was observed in venom-treated erythrocytes. Conclusion: Our results suggest that crude venom from Pelagia noctiluca alters cell membrane transport in human erythrocytes.
\end{abstract}

Copyright (C) 2013 S. Karger AG, Basel 
Morabito et al.: Crude Venom from Pelagia noctiluca Alters Ion Transport in Human Erythrocytes

\section{Introduction}

The Cnidaria members, Aiptasia mutabilis (Anthozoa) and Pelagia noctiluca (Scyphozoa), indigenous to the Strait of Messina (Italy) have become increasingly abundant in the recent years with no seasonality [1]. The accidental contact of humans with some Cnidaria specimens can produce severe local systemic pathologies and, in some cases, may lead to death $[2,3]$. The toxicity of these animals is manifested in part through delivery of toxins from nematocysts, specialized stinging organoids characteristic of the Phylum Cnidaria [4, 5]. Nematocysts have a three-layered capsule wall contained within highly specialized cells, termed nematocytes, which are located in tentacles, acontia and acrorhagi. The nematocyst occupies most of the nematocyte cytoplasm and is composed of an inverted tubule immersed in a capsular fluid in which toxins are stored $[6,7]$. The tubule is an extension of the wall structure, originating first outside the capsule and then invaginating within the wall. When both mechanical and chemical stimuli are applied, the nematocyst tubule rapidly everts to penetrate prey integuments, and then injects toxins. This response, termed discharge, represents a rapid form of exocytosis, occurs within $3 \mathrm{msec}[8,9]$ and is controlled by a complex mechanism that has still not been completely described. Compounds of protein nature have been isolated from Cnidaria venom, including pore-forming toxins (also called cytolysins), phospholipases, $\mathrm{Na}^{+}$and $\mathrm{K}^{+}$channel inhibitors, other neurotoxins and proteinase inhibitors [7, 10-19].

Erythrocytes are especially sensitive to oxidative stresses and it has been reported that biologically active compounds extracted from Cnidaria venom may cause cellular damage by inducing oxidative stress [7]. The oxidation of sulphydril (SH-) groups can result in conformational changes in Band 3, a protein mediating anion exchange (with specific regard to $\mathrm{Cl}^{-} / \mathrm{HCO}_{3}^{-}$) and whose structural integrity has a close relationship with $\mathrm{K}-\mathrm{Cl}$ cotransport [20]. Band 3 is composed of two functionally distinct domains: a C-terminal region responsible for catalyzing a one-to-one exchange of anions across the plasma membrane and an $\mathrm{N}$-terminal cytoplasmic domain anchored to the cytoskeleton [21].

In the present study, we investigated $\mathrm{K}^{+}$efflux, $\mathrm{SO}_{4}{ }^{2-}$ transport, the cellular redox state, as well as gross morphological changes in human erythrocytes elicited by treatment with $P$. noctiluca crude venom in the context of Band 3 and the KCC.

\section{Materials and Methods}

\section{Nematocyst isolation}

Specimens of the Scyphozoan Pelagia noctiluca were collected from the Strait of Messina (Sicily, Italy) during Spring/Summer 2012. Nematocysts were isolated from oral arms according to Salleo et al. [22]. Briefly, oral arms were excised from each specimen and nematocysts were isolated from the nematocytes via osmotic lysis in $4{ }^{\circ} \mathrm{C}$ distilled water. The resulting suspension was repeatedly filtered through plankton nets $\left(100 \mu \mathrm{m}, 60 \mu \mathrm{m}\right.$ and $40 \mu \mathrm{m}$ mesh) and spun (for $5 \mathrm{~min}$ at $4000 \mathrm{x} \mathrm{g}$ at $4{ }^{\circ} \mathrm{C}$ ) to discard debris. Once isolated, nematocysts were counted in a Burker chamber and processed for venom extraction or stored at $-20^{\circ} \mathrm{C}$ for later use.

\section{Venom extraction}

Samples containing 90-100 nematocysts/ $\mu$ l were re-suspended in physiological solution $(145 \mathrm{mM}$

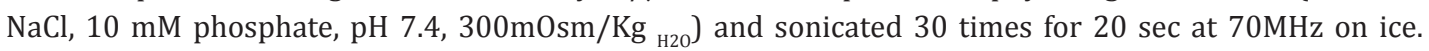
Nematocyst debris was separated by centrifugation (for $10 \mathrm{~min}$ at $4000 \mathrm{xg}$ at $4{ }^{\circ} \mathrm{C}$ ) and the supernatant used directly in biological assays.

\section{Erythrocyte preparation and sulphate transport measurement}

Human blood obtained after informed consent from 10 healthy volunteers was collected in heparinized tubes and centrifuged ( $5 \mathrm{~min}$ at $1000 \mathrm{x} \mathrm{g}$ ) in $150 \mathrm{mM} \mathrm{NaCl}, 20 \mathrm{mM}$ HEPES, pH 7.4. After centrifugation, the buffy coat was carefully removed. The sample was then re-suspended to $3 \%$ (for $\mathrm{SO}_{4}{ }^{2-}$ transport 
Morabito et al.: Crude Venom from Pelagia noctiluca Alters Ion Transport in Human Erythrocytes

measurement) or $20 \%$ (for $\mathrm{K}^{+}$efflux measurement, see below) haematocrit with isotonic medium (in mM: $118 \mathrm{Na}_{2} \mathrm{SO}_{4}, 20 \mathrm{HEPES}, 15$ glucose, $300 \mathrm{mOsm} / \mathrm{Kg}_{\text {н20 }}$ ), each time following 3, 5 min centrifugations at 1000 $\mathrm{x} g$. The osmotic pressure of all solutions was measured by a freezing point depression osmometer (Fiske, OS). After re-suspension, erythrocytes were treated with $0.05,0.1$ or $0.2 \% \mathrm{v} / \mathrm{v}$ crude venom at $25^{\circ} \mathrm{C}, \mathrm{pH} 7.4$. At specified intervals, $5 \mathrm{ml}$ samples of the suspensions were removed and added to a test tube containing $5 \mu \mathrm{M} 4,4$ '-diisothiocyanato-stilbene-2,2'-disulfonate (DIDS) stopping medium (10 ml) and kept on ice. The presence of DIDS, a compound that binds irreversibly and specifically to the extracellular moiety of the integral membrane Band 3 protein, inhibits $\mathrm{SO}_{4}{ }^{2-}$ transport in erythrocytes [23].

After the last sample withdrawal, erythrocytes were washed three times in sulphate-free medium (in mM: $150 \mathrm{NaCl}, 20$ HEPES, pH 7.4) at $0{ }^{\circ} \mathrm{C}$ and then hemolysed with $70 \% \mathrm{v} / \mathrm{v}$ thrichloroacetic acid (TCA). The membranes were then discarded by pelleting them with a $10 \mathrm{~min}, 4000 \mathrm{xg}$ at $4^{\circ} \mathrm{C}$ centrifugation. Sulphate ions in the supernatant were precipitated by sequentially adding and mixing $15 \mathrm{ml} 50 \%$ glycerol, $20 \mathrm{ml}$ $4 \mathrm{mM} \mathrm{NaCl}$ and $\mathrm{HCl}$ (hydrochloric acid 37\%) solution (12:1) and $15 \mathrm{ml} 124 \mathrm{mM} \mathrm{BaCl} \cdot 2 \mathrm{H}_{2} \mathrm{O}$ to obtain a homogeneous barium sulphate precipitate. The intracellular sulphate concentration was measured by atomic absorption spectrophotometry at $425 \mathrm{~nm}$. Using a calibrated standard curve, the absorption was converted to $\mathrm{mM}$ of intracellular $\mathrm{SO}_{4}{ }^{2-}$, which is necessary for calculating the rate constant from the following equation: $C_{t}=C_{\infty}\left(1-e^{-k t}\right)+C_{0}$, where $C_{t^{\prime}} C_{\infty}$ and $C_{0}$ represent the intracellular sulphate concentrations measured at times $\mathrm{t}, \infty$ and 0 , respectively. e indicates the Eulero number (2.7182818), $\mathrm{k}$ is a constant accounting for specific velocity of the process and $t$ is time at which intracellular $\mathrm{SO}_{4}{ }^{2-}$ concentration is measured $[24,25]$. This method is reproducible and the results do not vary more than $3 \%$. Sulfate uptake was measured as $\left[\mathrm{SO}_{4}^{2-}\right] \times 10^{-2} /$ cells.

\section{$K^{+}$efflux and cellular volume measurements}

For $\mathrm{K}^{+}$efflux measurements, according to Crupi et al. [26] with slight modifications, erythrocytes were re-suspended to $20 \%$ hematocrit with either isotonic media A (150 mM choline chloride, 20 mM HEPES, 15 $\mathrm{mM}$ glucose, $0.1 \mathrm{mM}$ ouabain, $307 \mathrm{mOsm} / \mathrm{Kg}_{\mathrm{H} 2 \mathrm{O}} \mathrm{pH}$ 7.4) or B (150 mM choline nitrate, $20 \mathrm{mM}$ HEPES, $15 \mathrm{mM}$ glucose, $0.1 \mathrm{mM}$ ouabain, $307 \mathrm{mOsm} / \mathrm{Kg}_{\mathrm{H} 2 \mathrm{O}}, \mathrm{pH} 7.4$ ) containing or not containing varying concentrations of venom or $2 \mathrm{mM} \mathrm{N}$-ethylmaleimide (NEM) for $1 \mathrm{~h}$ at $25^{\circ} \mathrm{C}$. The suspensions were spun at $4{ }^{\circ} \mathrm{C}$ for $5 \mathrm{~min}$ at $3000 \mathrm{xg}$ and $50 \mu \mathrm{l}$ of the supernatants were placed in $10 \mathrm{ml} 15 \mathrm{mM} \mathrm{LiNO}_{3}$.

Erythrocyte cell volume was measured by an ABX Pentra 120 hematology analyzer before $(t=0)$ and after incubation $(t=1 \mathrm{~h})$ with either medium $A$ or $B$, with or without venom or $2 \mathrm{mM} N \mathrm{NE}$ and expressed in femtoliters (fl). Prior to incubation $(\mathrm{t}=0)$, cellular volume ranged between 80-100 fl and was not altered by venom or NEM treatment $(\mathrm{t}=1 \mathrm{~h})$.

$\mathrm{K}^{+}$content of the medium was measured by a flame photometer and was corrected for the initial cell volume and expressed in $\mathrm{mEq} / \mathrm{L}$ red blood cells (RBCs) per $\mathrm{h}\left(\mathrm{mEq} / \mathrm{l} \mathrm{RBC} / \mathrm{h}\right.$ ). $\mathrm{K}^{+}$content was corrected since the cell suspensions were incubated for $1 \mathrm{~h}$ and possible volume changes were unable to be measured during that incubation time.

\section{Glutathione (GSH) measurement}

GSH concentration was measured in whole blood re-suspended to 3\% hematocrit before and after incubation with or without $0.05,0.1$ or $0.2 \%(\mathrm{v} / \mathrm{v})$ crude venom or $2 \mathrm{mM}$ NEM for $2 \mathrm{~h}$ at $25{ }^{\circ} \mathrm{C}$. After incubation, GSH levels were determined with Cayman's GSH assay kit that utilizes a carefully optimized enzymatic recycling method with glutathione reductase, according to the manufacturer's instructions and using the end point method [25]. The amount of oxidized glutathione (GSSG) was calculated with the following formula: $1 / 2 \mathrm{GSSG}=\mathrm{GSH}_{\text {total }}-\mathrm{GSH}_{\text {reduced }}$.

\section{Isolation of erythrocyte membrane proteins and determination of sulphydryl groups}

Intact erythrocytes (treated with or without $0.05,0.1$ or $0.2 \mathrm{v} / \mathrm{v}$ crude venom for $2 \mathrm{~h}$ at $25^{\circ} \mathrm{C}$ ) were washed with isotonic phosphate buffered saline (PBS, $5 \mathrm{mM} \mathrm{Na}_{2} \mathrm{HPO}_{4}, 150 \mathrm{mM} \mathrm{NaCl}, \mathrm{pH} 7.4$ ) and hemolyzed with 20 volumes of cold hypotonic buffer $\left(5 \mathrm{mM} \mathrm{Na}_{2} \mathrm{HPO}_{4}, 50 \mathrm{mM} \mathrm{NaCl}, \mathrm{pH} 7.4\right)$ to obtain a final concentration of $5 \%$ (cells/water). Membranes were pelleted by centrifugation at $20,000 \mathrm{xg}$ for $20 \mathrm{~min}$ at $0{ }^{\circ} \mathrm{C}$. The process was repeated with the same hypotonic buffer to remove hemoglobin [24]. One volume of membranes was then incubated with nine volumes of $0.1 \mathrm{M} \mathrm{NaOH}$ for $30 \mathrm{~min}$ at $0{ }^{\circ} \mathrm{C}$ in the presence of $0.2 \mathrm{mM}$ dithiothreitol (DTT) and $20 \mu \mathrm{g} / \mathrm{ml}$ phenylmethylsulfonil fluoride (PMSF). The samples were then centrifuged at 56,000 x $g$ 
Morabito et al.: Crude Venom from Pelagia noctiluca Alters Ion Transport in Human Erythrocytes

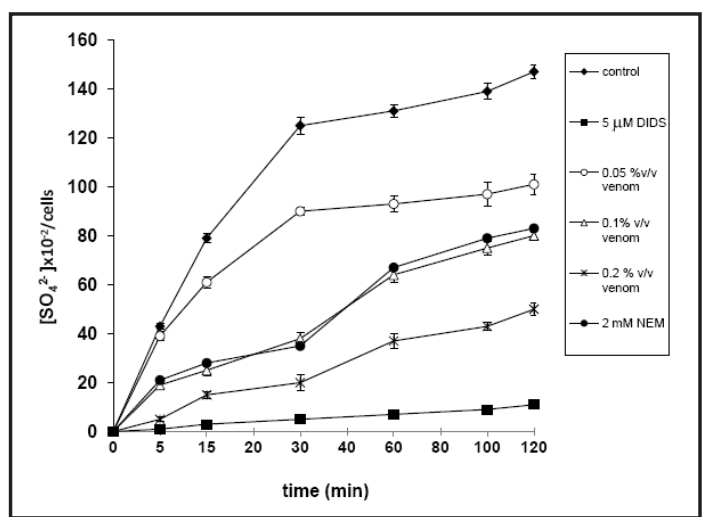

Fig. 1. Time course of $\mathrm{SO}_{4}^{2-}$ uptake in human erythrocytes treated with or without $0.05,0.1$, or $0.2 \% \mathrm{v} / \mathrm{v}$ crude venom isolated from $P$. noctiluca nematocysts, NEM $(2 \mathrm{mM})$ or DIDS $(5 \mu \mathrm{M})$. Bars represent the mean \pm SEM from at least 5 experiments.

\begin{tabular}{lcc}
\hline & $\begin{array}{c}\text { SO }_{4}{ }^{2} \text { uptake } \\
\text { Rate constant }\left[\mathrm{SO}_{4^{2}} \cdot\right] 10^{-2} / \text { cells min }^{-1}\end{array}$ & $\begin{array}{c}\text { \% decrease } \\
\text { vs control }\end{array}$ \\
\hline Control & $0.036 \pm 0.003$ & 0 \\
$0.05 \% \mathrm{v} / \mathrm{v}$ venom & $0.027 \pm 0.001^{*}$ & 25 \\
$0.1 \% \mathrm{v} / \mathrm{v}$ venom & $0.021 \pm 0.002^{*}$ & 42 \\
$0.2 \% \mathrm{v} / \mathrm{v}$ venom & $0.015 \pm 0.001^{*}$ & 58 \\
$2 \mathrm{mM} \mathrm{NEM}$ & $0.024 \pm 0.001^{*}$ & 33 \\
$5 \mu \mathrm{M}$ DIDS & $0.0011 \pm 0.001^{*}$ & 96 \\
\hline
\end{tabular}

Table 1. Rate constants $\mathrm{x}\left(\mathrm{min}^{-1}\right)$ of $\mathrm{SO}_{4}^{2-}$ uptake in human erythrocytes in the absence (control) or presence of $0.05,0.1,0.2 \% \mathrm{v} / \mathrm{v}$ crude venom isolated from $P$. noctiluca nematocysts, NEM (2 mM), or DIDS $(5 \mu \mathrm{M})$. Data are presented as means \pm SEM of at least 5 experiments where ${ }^{*} \mathrm{p}<0.05$ versus control (untreated) erythrocytes, as determined by one way ANOVA followed by Dunett's post hoc test

for $30 \mathrm{~min}$ at $0{ }^{\circ} \mathrm{C}$. The pellet was washed thrice with $5 \mathrm{mM} \mathrm{Na}_{2} \mathrm{HPO}_{4}, \mathrm{pH} 8.0$. Successively, $0.2 \mathrm{ml}$ of the pellet was solubilized for $30 \mathrm{~min}$ at $37^{\circ} \mathrm{C}$ with $0.3 \mathrm{ml} 20 \%$ sodium dodecyl sulphate (SDS) and $3 \mathrm{ml} \mathrm{Na}_{2} \mathrm{HPO}_{4} \mathrm{pH}$ 8.0. Next, $0.1 \mathrm{ml} 10 \mathrm{mM} \mathrm{5,5'-dithiobis-(2-nitrobenzoic} \mathrm{acid)} \mathrm{(DTNB)} \mathrm{in} 100 \mathrm{mM} \mathrm{Na}_{2} \mathrm{HPO}_{4}$, $\mathrm{pH} 8.0$ was added and incubated for $20 \mathrm{~min}$ at $37^{\circ} \mathrm{C}$. The absorbance of the solution at $405 \mathrm{~nm}$ was then measured. Using a standard curve obtained from at least five samples of known GSH concentrations (dissolved in physiological saline), the absorbance measured from the experimental samples was converted to $\mu \mathrm{g} / \mathrm{ml}$ of thiol groups.

\section{Erythrocytes staining with Giemsa}

The erythrocytes underwent Giemsa staining, for detecting possible morphological alterations to cell membrane. Giemsa stain is a classic blood film stain using Giemsa's solution (Sigma-Aldrich, Milan, Italy), a mixture containing methylene blue, eosin and Azure B. A slide with blood smear, fixed with pure methanol for 30 seconds, was immersed in 5\% Giemsa stain solution for 20-30 minutes. Stained erythrocytes were observed under a Zeiss Axio Imager ZI connected to a video camera and then counted. Percentage of damaged cells (with altered shape compared to control cells, see arrows in Fig. 4) was calculated by correlating their number to the total number of cells.

\section{Statistics}

Data are expressed as mean values \pm SEM. Statistical analyses were performed using paired Student's $t$ test or a one-way ANOVA where appropriate. $\mathrm{p}<0.05$ was considered statistically significant.

\section{Results}

P. noctiluca crude venom inhibits sulphate uptake in human red blood cells

A time course of $\mathrm{SO}_{4}^{2-}$ uptake (as a measure for the level of anion transport) in human erythrocytes treated with or without different concentrations of crude venom $(0.05,0.1$ and $0.2 \mathrm{v} / \mathrm{v})$, the sulfhydryl alkylating agent NEM $(2 \mathrm{mM})$ or the Band 3 inhibitor DIDS ( $5 \mu \mathrm{M})$ is shown in Fig. 1, and the rate constants for $\mathrm{SO}_{4}{ }^{2-}$ uptake are shown in Table 1. $5 \mu$ M DIDS was chosen to ensure total inhibition of the Band 3 protein [27, 28]. NEM induces cell shrinkage and alterations in the redox state, as well as increases the phosphorylation of Band 3 at tyrosine residues [29]. All treatments significantly reduced the rate of $\mathrm{SO}_{4}{ }^{2-}$ uptake $(\mathrm{p}<0.05)$ compared to controls. In addition, erythrocytes treated with NEM, DIDS, $0.1 \%$ and $0.2 \%$ venom exhibited similar degrees of saturation. None of the treatments induced hemolysis in human erythrocytes, as assessed by the Trypan blue exclusion test (data not shown). 


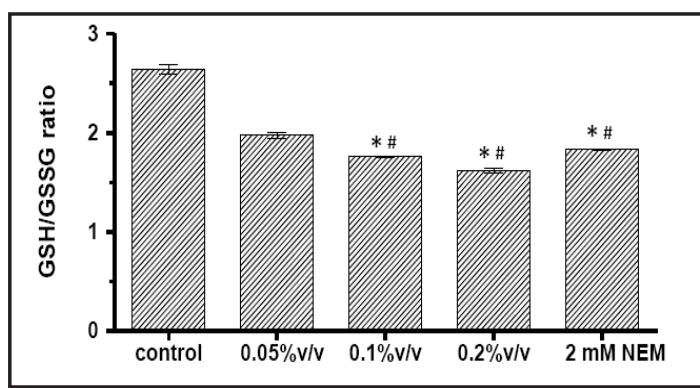

Fig. 2. GSH/GSSG ratios in human erythrocytes treated with or without $0.05,0.1,0.2 \% \mathrm{v} / \mathrm{v}$ crude venom isolated from $P$. noctiluca nematocysts or NEM ( $2 \mathrm{mM}$ ) for $2 \mathrm{~h}$. Bars represent the mean \pm SEM from 5 experiments where ${ }^{*} \mathrm{p}<0.05$ versus control (untreated) erythrocytes, \# p $<0.05$ versus $0.05 \% \mathrm{v} / \mathrm{v}$ venom-treated erythrocytes, as determined by one way ANOVA followed by Dunett's post hoc test.

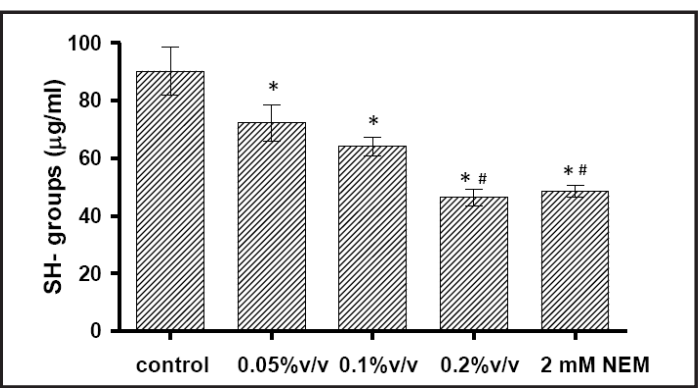

Fig. 3. SH- groups estimation $(\mu \mathrm{g} / \mathrm{ml})$ in human erythrocytes treated with or without $0.05,0.1$, $0.2 \% \mathrm{v} / \mathrm{v}$ crude venom isolated from $P$. noctiluca nematocysts or NEM (2mM) for $2 \mathrm{~h}$. Bars represent the mean \pm SEM of 5 experiments where $* \mathrm{p}<0.05$ versus control (untreated) erythrocytes, \# $\mathrm{p}<0.05$ versus $0.05 \% \mathrm{v} / \mathrm{v}$ venom-treated erythrocytes, as determined by one way ANOVA followed by Dunett's post hoc test.

Table 2. Reduced (GSH) and oxidized (GSSG) glutathione ( $\mu \mathrm{mol} / \mathrm{L}$ of cells), as well as the GSH/GSSG ratios in human erythrocytes treated with or without $0.05,0.1,0.2 \% \mathrm{v} / \mathrm{v}$ crude venom isolated from $P$. noctiluca nematocysts or NEM ( $2 \mathrm{mM}$ ) for $2 \mathrm{~h}$. Values represent means \pm SEM of at least 5 experiments where $* \mathrm{p}<0.05$ versus control (untreated) erythrocytes, \# $\mathrm{p}<0.05$ versus $0.05 \% \mathrm{v} / \mathrm{v}$ venom-treated erythrocytes, as determined by one way ANOVA followed by Dunett's post hoc test.

\begin{tabular}{|c|c|c|c|c|c|}
\hline \multirow[b]{2}{*}{ Metabolites } & \multirow[b]{2}{*}{ control } & \multicolumn{3}{|c|}{ Venom (\% v/v) } & \multirow{2}{*}{$\begin{array}{l}N E M \\
2 \mathrm{mM}\end{array}$} \\
\hline & & 0.05 & 0.1 & 0.2 & \\
\hline $\mathrm{SH}(\mu \mathrm{mol} / \mathrm{L})$ & $744.31 \pm 37$ & $698 \pm 26$ & $651 \pm 22^{*} \#$ & $611 \pm 19 * \#$ & $595 \pm 30^{*} \#$ \\
\hline $\mathrm{SSG}(\mu \mathrm{mol} / \mathrm{L})$ & $281.35 \pm 13$ & $353 \pm 15$ & $370 \pm 11^{*} \#$ & $377 \pm 12^{*} \#$ & $325 \pm 22^{*} \#$ \\
\hline SH/GSSG & $2.645 \pm 0.05$ & $1.977 \pm 0.03$ & $1.759 \pm 0.01^{* \#}$ & $1.62 \pm 0.03^{*} \#$ & $1.83 \pm 0.01 * \#$ \\
\hline
\end{tabular}

Table 3. $\mathrm{K}^{+}$efflux measured in human erythrocytes in the absence (control) or presence of $0.2 \% \mathrm{v} / \mathrm{v}$ crude venom from $P$. noctiluca nematocysts or NEM $(2 \mathrm{mM})$ for $1 \mathrm{~h}$ in either $\mathrm{Cl}^{-}$containing or $\mathrm{Cl}^{-}$free medium. Data are presented as means \pm SEM of at least 5 experiments where ${ }^{*} \mathrm{p}<0.05$ versus control (untreated) erythrocytes as determined by one way

\begin{tabular}{cccc}
\hline & \multicolumn{3}{c}{$K^{+}$meq/L cells $\times h$} \\
& control & $0.2 \% \mathrm{v} / \mathrm{v}$ venom & NEM $(2 \mathrm{mM})$ \\
\hline $\mathrm{Cl}^{-}$ & $6.1 \pm 0.1$ & $37.3 \pm 0.2^{*}$ & $38.5 \pm 0.1^{*}$ \\
$\mathrm{NO}_{3}{ }^{-}$ & $4.2 \pm 0.1$ & $8.2 \pm 0.1^{*}$ & $8.4 \pm 0.1^{*}$ \\
\hline
\end{tabular}
ANOVA followed by Dunett's post hoc test

\section{P. noctiluca crude venom decreases GSH and sulphydryl group levels in human red blood cells}

GSH functions as an antioxidant with free radical scavenging activity, resulting in the oxidation of GSH to glutathione disulfide (GSSG). Accordingly, the GSH/GSSG ratio acts as a gauge for the intracellular redox state, where decreases in the GSH/GSSG ratio are indicative of oxidative stress. Treatment of erythrocytes with $0.1 \%$ and $0.2 \% \mathrm{v} / \mathrm{v}$ crude venom, as well as with NEM, significantly decreased the GSH/GSSG ratio (Fig. 2 and Table 2). These data suggest that the crude venom isolated from P. noctiluca nematocysts induces oxidative stress.

The concentration of $\mathrm{SH}$ - groups, as an indicator of possible alterations in the tertiary structure of integral membrane proteins, is depicted in Fig 3. These data show a significant reduction in the concentration of $\mathrm{SH}$ - groups $(\mu \mathrm{g} / \mathrm{ml})$ in integral membrane proteins after 
Fig. 4. Assessment of morphology in human erythrocytes treated without (A) or with (B) $0.2 \% \mathrm{v} / \mathrm{v}$ crude venom isolated from $P$. noctiluca nematocysts for 100 minutes by Giemsa staining. Bar = $20 \mu \mathrm{m}$. Arrows indicate erythrocytes with altered shape compared to the control (untreated) erythrocytes.

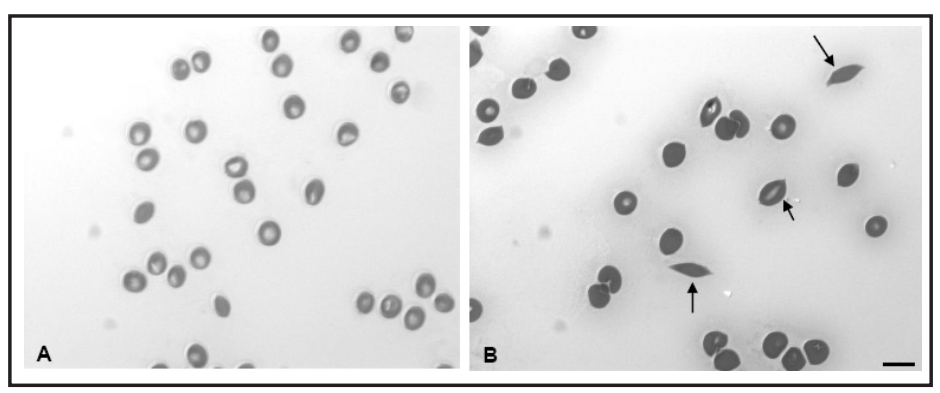

Fig. 5. Percentage of damaged human erythrocytes treated with or without $0.05,0.1$ and $0.2 \% \mathrm{v} / \mathrm{v}$ crude venom isolated from $P$. noctiluca nematocysts for $100 \mathrm{~min}$. Bars represent the mean \pm SEM of 5 experiments where ${ }^{*} \mathrm{p}<0.05$ versus control (untreated) erythrocytes, \# p $<0.05$ versus $0.05 \%$ $\mathrm{v} / \mathrm{v}$ venom-treated erythrocytes, as determined by one way ANOVA followed by Dunett's post hoc test.

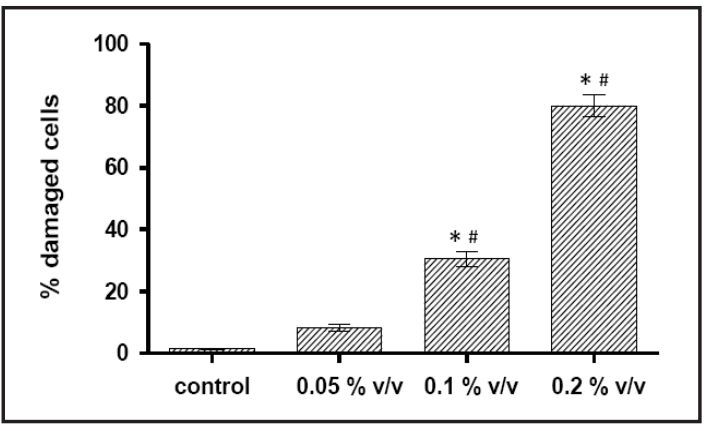

treatment with increasing concentrations of crude venom. A significant decrease in the concentration of SH- groups was also seen following NEM treatment, suggesting that the crude venom may induce damage to erythrocyte integral membrane proteins similarly to NEM.

P. noctiluca crude venom elicits a $\mathrm{Cl}$-dependent $\mathrm{K}^{+}$efflux in human erythrocytes

Table 3 shows the $\mathrm{K}^{+}$efflux ( $\mathrm{mEq} / \mathrm{l} \mathrm{RBC} / \mathrm{h}$ ) measured in human erythrocytes treated with or without $0.2 \% \mathrm{v} / \mathrm{v}$ venom or NEM. Both treatments significantly increased $\mathrm{K}^{+}$efflux compared to the control, so that, according to what was previously observed by Adragna and Lauf [30] on NEM-treated erythrocytes, a possible oxidative effect of crude venom on a $\mathrm{K}^{+}$ transport system, putatively KCC, can be suggested.

To better verify the $\mathrm{Cl}^{-}$-dependence of $\mathrm{K}^{+}$efflux altered by treatment of erythrocytes with crude venom, $\mathrm{K}^{+}$efflux was measured in either $\mathrm{Cl}^{-}$-containing or in $\mathrm{Cl}^{-}$-free medium, by replacing $\mathrm{Cl}^{-}$with $\mathrm{NO}_{3}$; and compared with that measured after NEM treatment (Table 3). In $\mathrm{Cl}^{-}$-free conditions, $\mathrm{K}^{+}$efflux in venom-treated cells was significantly reduced from 37.3 to $8.2 \mathrm{mEq} / \mathrm{l} \mathrm{RBC} / \mathrm{h}$ and, in NEM- treated cells, was significantly reduced from 38.5 to 8.4 $\mathrm{mEq} / \mathrm{l} \mathrm{RBC} / \mathrm{h}$ (inhibited by $80 \%$, $\mathrm{p}<0.05$, Student's t-test).

P. noctiluca crude venom alters the morphological state of human erythrocytes

Upon light microscope observations, $0.2 \% \mathrm{v} / \mathrm{v}$ crude venom-treated erythrocytes exhibited morphological alterations, like increased cell membrane deformability, compared to the control (Fig. 4). A similar effect was observed in erythrocytes exposed to $0.1 \% \mathrm{v} / \mathrm{v}$ venom (data not shown). NEM treatment, as already shown [30], induced cell shrinkage, while the exposure of erythrocytes to $0.05 \% \mathrm{v} / \mathrm{v}$ crude venom did not induce any morphological change (data not shown).

After treatment with different concentrations of crude venom, damaged erythrocytes were counted (Fig. 5). No increase in damaged cells was detected with the lowest venom dose $(0.05 \% \mathrm{v} / \mathrm{v})$, whereas higher doses $(0.1$ and $0.2 \% \mathrm{v} / \mathrm{v})$ resulted in a significant increase in damaged erythrocytes with respect to the control $(30 \% \pm 5$ and $80 \% \pm 6$ respectively, $\mathrm{p}<0.05$ ). 
Morabito et al.: Crude Venom from Pelagia noctiluca Alters Ion Transport in Human Erythrocytes

\section{Discussion}

NEM (0.5-2 mM) was previously shown to activate $\mathrm{K}-\mathrm{Cl}$ cotransport in human, rabbit and sheep erythrocytes [31-33], activate the tetramer-to-dimer transition of spectrin (attributed to a weakened interaction between ankyrin and AE1/Band 3) [34], and alter the activity of protein phosphatase 1 and 2A (serine phosphatases) [35], calpain-1 [36] and the tyrosine phosphatase SHP1 (Src homology phosphatase-1) [37]. Band 3 is mainly phosphorylated at three tyrosine residues $(8,21$, and 46) in the cytoplasmic domain [38]. In particular, Band 3 phosphorylation has been associated with membrane deformability, suggesting that the visco-elastic properties of human erythrocytes may be regulated by Band 3 tyrosine phosphorylation [39]. Other studies using erythrocytes suggested that swelling-activated transport via KCC and shrinkage-activated transport via NKCC are virtually inactive in isosmotic artificial medium since they are co-ordinately controlled by a common mechanism termed "volume set point". Treatment with oxidant agents reduces the "volume set point" and activates KCC [32]. The decreased efficiency of anion transport observed following NEM treatment could either be due to alterations in the structural state of Band 3 (by SH-group oxidation, for example) or to cell shrinkage (by increased $\mathrm{K}^{+}$efflux). The latter hypothesis is substantiated by the fact that NEM, while activating a $\mathrm{K}^{+}$efflux (Table 3 ), also reduced $\mathrm{SO}_{4}{ }_{4}^{2-}$ uptake (Fig. 1). Regarding the former aspect, the decrease in GSH levels (Table 2) detected in cells treated either with NEM or different venom concentrations is indicative of oxidative stress. A decrease in SH-groups in integral membrane proteins (Fig. 3), consistent with decreased GSH concentrations (Fig. 2), was also detected in venom-treated cells. Interestingly, oxidative stress is known to cross-link integral membrane proteins and hemoglobin with Band 3, leading to the formation of high molecular- mass aggregates [30,4041] and accompanying decreases in GSH levels and oxidation of membrane thiols [42].

The finding that low concentrations of crude venom from $P$. noctiluca may provoke oxidative stress on erythrocyte membrane proteins provides novel information about its mechanism of action. As far as marine toxins are concerned, some of them are defined as cytolytic or neurotoxic, and target different animals, such as insects, crustaceans and vertebrates, at the level of membrane transport systems, including voltage-gated $\mathrm{Na}^{+}$and $\mathrm{K}^{+}$channels and acid-sensing ion channels [7, 43]. In this respect, palytoxin-group toxins (PITX) extracted from the tropical microalga Ostreopsis ovata, exert their potent biological activity by altering ion homeostasis mechanisms in excitable and non-excitable tissues [44]. Specifically, PITX induces a massive intracellular $\mathrm{Na}^{+}$influx via modulation of the $\mathrm{Na}^{+} / \mathrm{K}^{+}$ ATPase [45]. These authors suggested that such $\mathrm{Na}^{+}$overload is the crucial step in mediating overproduction of ROS and cell death in human HaCaT keratinocytes. It has also been described that oxidative stress promoted by different drugs, through a direct interaction with hemoglobin, may lead to the activation of caspase 3, which, in turn, influences anion flux via Band 3, as well as glucose metabolism [46]. In addition, it was recently described that non-lytic doses of $P$. noctiluca crude venom directly induces mitochondrial trans-membrane potential collapse and generation of reactive oxygen species (ROS) in SH-SY5Y cells derived from human neuroblastoma [47].

Our results show that both crude venom- and NEM-treated erythrocytes exhibit, in addition to a reduction in SH- groups, an increased $\mathrm{Cl}^{-}$-dependent $\mathrm{K}^{+}$efflux (Table 3). In this regard, it has been demonstrated that treatment with thiol-oxidizing and alkylating agents, such as diamide, NEM or orthovanadate lead to alterations in both the erythrocyte redox state and in the activation of KCC, thus resulting in cell shrinkage [30]. On this basis, the hypothesis that non-hemolytic doses of $P$. noctiluca crude venom may interfere with membrane transport is reinforced, since it can provoke oxidative stress by reducing $\mathrm{SH}$ groups, as well as activate $\mathrm{Cl}^{-}$-dependent $\mathrm{K}^{+}$efflux, similarly to NEM. Moreover, an increase in $\mathrm{K}^{+}$efflux is further supported by the changes in erythrocyte morphology observed after exposure to either crude venom or NEM. In both cases, erythrocyte shrinkage was detected. Oxidative damage to erythrocyte membranes may increase the permeability to $\mathrm{K}^{+}$ions via increased activity of KCC, as reported by Crupi et al. [26]. 
Morabito et al.: Crude Venom from Pelagia noctiluca Alters Ion Transport in Human Erythrocytes

\section{Conclusion}

In conclusion, the present study provides novel findings about the biological activity of crude venom isolated from P. noctiluca nematocysts. Our findings may contribute to uncovering the mechanism of action of biologically active compounds extracted from marine animal venoms - a theme that has been under much debate [7].

\section{Conflict of Interests}

The Authors have no conflicts of interest to disclose.

\section{Acknowledgement}

This work was supported by funding from the Italian Ministry for Research and University

\section{References}

1 Rosa S, Pansera M, Granata A, Guglielmo L: Interannual variability, growth, reproduction and feeding of Pelagia noctiluca (Cnidaria: Scyphozoa) in the Strait of Messina (Central Mediterranean Sea): Linkages with temperature and diet. J Mar Syst 2013;111-112:97-107.

-2 Carrette TJ, Underwood AH, Seymour JE: Irukandji syndrome: a widely misunderstood and poorly researched tropical marine envenoming. Diving Hyperb Med 2012;42:214-223.

-3 Tibballs J: Australian venomous jellyfish, envenomation syndromes, toxins and therapy. Toxicon 2006;48:830-859.

4 Hessinger DA, Lenhoff H (eds): The biology of nematocysts. Academy Press, San Diego, 1988, pp 25-40.

5 Beckmann A, Özbek S: The nematocyst: a molecular map of the cnidarian stinging organelle. Int J Dev Biol 2012;56:577-582.

6 La Spada G, Marino A, Sorrenti G: Anatomical and physiological characteristics of tentacular nematocytes isolated by different methods from Aiptasia diaphana. (Cnidaria: Anthozoa) in the brackish pond Faro (Messina, Italy); in Faranda FM, Guglielmo L, Spezie G (eds): Mediterranean Ecosystems, Springer Milan, 2001, pp 297-303.

7 Frazão B, Vasconcelos V, Antunes A: Sea anemone (Cnidaria, Anthozoa, Actiniaria) toxins: an overview. Mar Drugs 2012;10:1812-1851.

- 8 Holstein T, Tardent P: An ultrahigh-speed analysis of exocytosis: nematocyst discharge. Sciences 1984;223:830-833.

-9 Ozbek S, Balasubramanian PG, Holstein TW: Cnidocyst structure and the biomechanics of discharge. Toxicon 2009;54:1038-1045.

10 Wang Y, Chua KL, Khoo HE: A new cytolysin from the sea anemone Heteractis magnifica: isolation, cDNA cloning and functional expression. Biochem Biophys Acta 2000;1478:9-18.

11 Anderluh G, Macek P: Cytolytic peptide and protein toxins from sea anemone (Anthozoa: Actiniaria). Toxicon 2002;40:111-124.

12 Grotendorst GR, Hessinger DA: Purification and partial characterization of the phospholipase $\mathrm{A}_{2}$ and colytic factor from sea anemone (Aiptasia pallida) nematocyst venom. Toxicon 1999;37:1779-1796.

13 Norton RS: Structure and structure-function relationships of the sea anemone proteins that interact with the sodium channel. Toxicon 1991;29:1051-1084.

14 Minagawa S, Ishida M, Nagashima Y, Shiomi K: Primary structure of a potassium channel toxin from the sea anemone Actinia equina. FEBS Letters 1998;427:149-151.

15 Garateix A, Vega R, Salceda E, Cebada J, Aneiros A: BgK anemone toxin inhibits outward K+ currents in snail neurons. Brain Res 2000;864:312-314. 
Morabito et al.: Crude Venom from Pelagia noctiluca Alters Ion Transport in Human Erythrocytes

16 Delfin Y, Gonzalez Y, Diaz M, Chavez M: Proteinase inhibitor from Stichodactyla helianthus: purification, characterization and immobilization. Arch Med Res 1994;25:199-204.

17 Beeton C, Pennington MW, Norton RS: Analogs of the sea anemone potassium channel blocker ShK for the treatment of autoimmune diseases. Inflamm Allergy Drug Targets 2011;10:313-321.

-18 Rodríguez AA, Salceda E, Garateix AG, Zaharenko AJ, Peigneur S, López O, Pons T, Richardson M, Díaz M, Hernández Y, Ständker L, Tytgat J, Soto E: A novel sea anemone peptide that inhibits acid-sensing ion channels. Peptides. In press. DOI:pii: S0196-9781(13)00220-9.

19 Nesher N, Shapira E, Sher D, Moran Y, Tsveyer L, Turchetti-Maia AL, Horowitz M, Hochner B, Zlotkin E: AdE-1, a new inotropic $\mathrm{Na}^{+}$channel toxin from Aiptasia diaphana, is similar to, yet distinct from, known anemone $\mathrm{Na}^{+}$channel toxins. Biochem J 2013;451:81-90.

-20 Salhany JM, Sloan RL, Cordes KS: The carboxyl side chain of glutamate 681 interacts with a chloride binding modifier site that allosterically modulates the dimeric conformational state of band 3 (AE1). Implications for the mechanism of anion/proton cotransport. Biochem 2003;42:1589-1602.

-21 Reithmer RAF: The erythrocytes anion transporter (band 3). Curr Opin Struct Biol 1993;3:515-523.

22 Salleo A, La Spada G, Falzea G, Denaro MG: Discharging effectiveness of lyotropic anions on nematocysts of Pelagia noctiluca. Mol Physiol 1983;6:19-26.

23 Romano L, Scuteri A, Gugliotta T, Romano P, De Luca G, Sidoti A, Amato A: Sulphate influx in the erythrocytes of normotensive, diabetic and hypertensive patients. Cell Biol Int 2002;26:421-426.

24 Romano L, Peritore D, Simone E, Sidoti A, Trischitta A, Romano P: Chloride-sulphate exchange chemically measured in human erythrocytes ghosts. Cell Mol Biol 1998;44:351-355.

25 Teti D, Crupi M, Busà M, Valenti A, Loddo S, Mondello M, Romano L: Chemical and pathological oxidative influences on band 3 protein anion-exchanger. Cell Physiol Biochem 2005;16:77-86.

26 Crupi M, Romano L, Romano P, Venza M, Venza I ,Teti D: Erythrocytes anion transport and oxidative change in $\beta$-thalassaemias. Cell Biol Int 2010;34:655-662.

-27 Lepke S, Fasold H, Pring M, Passow H: A study of the relationship between inhibition of anion exchange and binding to the red blood cell membrane of 4,4'-diisothiocyano stilbene-2,2'-disulfonic acid (DIDS) and its dihydro derivative (H2DIDS). J Membr Biol 1976;29:147-177.

28 Gugliotta T, De Luca G, Romano P, Rigano C, Scuteri A, Romano L: Effects of lead chloride on human erythrocyte membranes and on kinetic anion sulphate and glutathione concentrations. Cell Mol Biol Lett 2012;17:586-597.

29 Minetti G, Seppi C, Ciana A, Balduini C, Low PS, Brovelli A: Characterization of the hypertonically induced tyrosine phosphorylation of erythrocyte band 3. Biochem J 1998;335:305-311.

30 Adragna NC, Lauf PK: Oxidative activation of K-Cl co-transport by diamide in erythrocytes from humans with red cell disorders, and from several other mammalian species. J Membrane Biol 1997;155:207-217.

- 31 Lauf PK, Adragna NC, Dupre N, Bouchard JP, Rouleau GA: K-Cl cotransport in red blood cells from patients with KCC3 isoform mutants. Biochem Cell Biol 2006;84:1034-1044.

-32 Lauf PK, Adragna NC: K-Cl cotransport: properties and molecular mechanism. Cell Physiol Biochem 2000;10:341-354.

-33 Lauf PK, Adragna NC: Twenty-five years of K-Cl cotransport: from stimulation by a thiol reaction to cloning of the full-length KCCs. Adv Exp Med Biol 2004;559:11-28.

-34 Blanc L, Salomao M, Guo X et al: Control of erythrocyte membrane-skeletal cohesion by the spectrinmembrane linkage. Biochemistry 2010;49:4516-4523.

-35 Bize I, Guvenc B, Buchbinder G, Brugnara C: Stimulation of human erythrocyte K-Cl cotransport and protein phosphatase type 2A by n-ethylmaleimide: role of intracellular $\mathrm{Mg}^{2+}$. J Membr Biol 2000;177:159168.

-36 Glaser T, Schwarz-Benmeir N, Barnoy S, Barak S, Eshhar Z, Kosower NS: Calpain (Ca ${ }^{2+}$-dependent thiol protease) in erythrocytes of young and old individuals, Proc Natl Acad Sci USA 1994;91:7879-7883.

37 Bragadin M, Ion-Popa F, Clari G, Bordin L: SHP-1 tyrosine phosphatase in human erythrocytes. Ann N Y Acad Sci 2007;1095:193-203.

-38 Yannoukakos D, Meyer HE, Vasseur C, Driancourt C, Wajcman H, Bursaux E: Three regions of erythrocyte band 3 protein are phosphorylated on tyrosines: characterization of the phosphorylation sites by solid phase sequencing combined capillary electrophoresis. Biochim Biophys Acta 1991;1066:70-76.

-39 Barbul A, Zipser Y, Nachles A, Korenstein R: Deoxygenation and elevation of intracellular magnesium induce tyrosine phosphorylation of band 3 in human erythrocytes. FEBS Lett 1999;455:87-91. 


\section{Cellular Physiology}

and Biochemistry

Morabito et al.: Crude Venom from Pelagia noctiluca Alters Ion Transport in Human Erythrocytes

40 Datta P, Dasgupta A, Singh AK, Mukherjee P, Kundu M, Basu J: Interaction between FtsW and penicillinbinding protein 3 (PBP3) directs PBP3 to mid-cell, controls cell septation and mediates the formation of a trimeric complex involving FtsZ, FtsW and PBP3 in mycobacteria. Mol Microbiol 2006;62:1655-1673.

41 Henning SM, Zhang JZ, McKee RW, Swendseid ME, Jacob RA: Glutathione blood levels and other oxidant defense indices in men fed diets low in vitamin C. J Nutr 1991;121:1969-1975.

42 Oliveri MB, Mautalen C, Bustamante L, Gómez García V: Serum levels of 25-hydroxyvitamin D in a year of residence on the Antarctic continent. Eur J Clin Nutr 1994;48:397-401.

43 Al Sabi A, McArthur J, Ostroumov V, French RJ: Marine toxins that target voltage-gated sodium channels. Mar Drugs 2006;4:157-192.

44 Rossini GP, Bigiani A: Palytoxin action on the $\mathrm{Na}^{+}, \mathrm{K}^{+}-\mathrm{ATPase}$ and the disruption of ion equilibria in biological systems. Toxicon 2011;57:429-439.

45 Pelin M, Ponti C, Sosa S, Gibellini D, Florio C, Tubaro A: Oxidative stress induced by palytoxin in human keratinocytes is mediated by a H+-dependent mitochondrial pathway. Toxicol Appl Pharmacol 2013;266:18.

46 Tellone E, Ficarra S, Giardina B, Scatena R, Russo A, Clementi ME, Misiti F, Bellocco E, Galtieri A: Oxidative effects of gemfibrozil on anion influx and metabolism in normal and Beta-thalassemic erythrocytes: physiological implications. J Membr Biol 2008;224:1-8.

47 Morabito R, Condello S, Currò M, Marino A, Ientile R, La Spada G: Oxidative stress induced by crude venom from the jellyfish Pelagia noctiluca in neuronal-like differentiated SH-SY5Y cells. Toxicol In Vitro 2012;26:694-699. 